\title{
Making the Law Work for Men and Women: Advancing Gender Equality and Non-Discrimination in Nigeria's Anti-Open Grazing Laws
}

\section{Jane Ezirigwe}

To cite this article: Jane Ezirigwe (2020) Making the Law Work for Men and Women: Advancing Gender Equality and Non-Discrimination in Nigeria's Anti-Open Laws, The Journal of Sustainable Development, Law and Policy, $11: 2,362-381$.

To link to this article: https://dx.doi.org/10.4314/jsdlp.v11i2.4 


\title{
Making the Law Work for Men and Women: Advancing Gender Equality and Non-Discrimination in Nigeria's Anti-Open Grazing Laws
}

\author{
Jane Ezirigwe*
}

(Received 20 October 2020; final version received 24 November 2020)

The realization of equality between men and women is a fundamental part of the international development agenda. This entails equal opportunities and elimination of all forms of discrimination. Discrimination can be embedded overtly or covertly in laws. Therefore, making the law work for both men and women demands an all-inclusive approach. In Nigeria, the crisis involving herders and farmers has led to the loss of lives and properties, internal displacement, and human right abuses including rape. In a bid to curb the crisis, 'anti-open grazing' laws have been made in some states. Most of the acts criminalized and offences prohibited were gender-neutral, despite a more embracing approach on gender sensitivity in lawmaking.

This article adopts an evaluative approach to assess inclusivity in the recent anti-open grazing laws in Nigeria. It argues that the laws covertly promote patriarchal benefits and boost hegemonic male dominance. Its aim is to reveal that gender-specific circumstances which reinforce sexual and gender-based violence against women, including rape, were ignored. This is notwithstanding the fact that the bodies of women and girls have been turned into battlefields. The study suggests that because society is not homogeneous, there is a need to reflect this diversity by updating these laws, to make them inclusive, in offering protection to women. It recommends that since equal opportunities come with equal responsibilities, the need to identify and prohibit the roles of women in the crisis becomes pertinent. This makes the laws work for both men and women, in pursuit of their agricultural endeavours.

Keywords: farmers-herders conflict; discrimination; rape; gender mainstreaming; anti-open grazing laws

\section{INTRODUCTION} he current discourse on gender equality has shifted from a
focus on equality as a rule of law principle to equality as a beneficial building block in accelerating development. ${ }^{1}$

* LLB (Hons.) Abuja, LLM (London), MBA (EBS), Doctoral Scholar, University of Cape Town, South Africa; Research Fellow, Nigerian Institute of Advanced Legal Studies; ezirigwejane@gmail.com. 
Therefore, the realization of equality between women and men is a fundamental part of the international development agenda. ${ }^{2}$ This entails equal opportunities ${ }^{3}$ and elimination of all forms of discrimination. ${ }^{4}$ Discrimination can be embedded overtly or covertly in laws. To develop progressive and inclusive societies, the law needs to recognise the structural and socio-cultural nuances of gender and contemplate how gender dynamics influence regular interactions and experiences. ${ }^{5}$ A pertinent question will then be, does a law enhance or devalue its liberation potential to protect all? Where it does not enhance all-inclusive protection, then the law is discriminatory.

In Nigeria, the crisis involving herders and farmers has led to the loss of several lives, ${ }^{6}$ destruction of properties worth billions of naira, internal displacement, ${ }^{8}$ and

1 Catherine Powell, 'Gender Indicators as Global Governance: Not Your Father's World Bank' (2016) 17 Geo. J. Gender \& L. 777, 787

2 Sustainable Development Goal 5, 'Achieve gender equality and empower all women and girls'. Decisions by Topic: Gender equality and women's empowerment, <https://sustainabledevelopment.un.org/topics/women /-decisions > accessed 9 July 2019.

3 Under Goal 5.5, 'Ensure women's full and effective participation and equal opportunities for leadership at all levels of decision- making in political, economic and public life.' Ibid.

4 Under Goal 5.1 'End all forms of discrimination against all women and girls everywhere, and Goal 5.2 Eliminate all forms of violence against all women and girls in the public and private spheres, including trafficking and sexual and other types of exploitation", Ibid.

5 Adam R. Chang and Stephanie M. Wildman, 'Gender In/sight: Examining Culture and Constructions of Gender' (2017) 18 Geo. J. Gender \& L. 43, 45 .

6 Edegbe Odemwingie, 'Nigeria: The Grazing Routes To Ethnic Bloodshed' Leadership Newspaper (28 November 2014) <http://leadership .ng/features/392080/nigeria-grazing-routes-ethnic-bloodshed $>$ accessed 27 April 2019; 'Embracing Agatu/ Fulani Herdsmen Peace Initia-tive’ Nigerian Pilot (11 February 2017) <http://nigerianpilot.com/embraci ng-agatu-fulani-herdsmen-peace-initiative-2/> accessed 20 April 2019.

7 Samuel Ogundipe and Josiah Oluwole 'Nigeria loses \$14 billion annually to herdsmen-farmers clashes - Report' Premium Times (15 April 2016) <https://www.premiumtimesng.com/news/headlines/201829 nigeria-loses-14-billion-annually-herdsmen-farmers-clashes report.html> accessed 2 July 2019.

8 Odoh, S.I and Chilaka Francis Chigozie, 'Climate Change And Conflict In Nigeria: A Theoretical And Empirical Examination of the Worsening Incidence of Conflict Between Fulani Herdsmen and Farmers in 
human right abuses including rape. ${ }^{9}$ In a bid to curb the crisis and prevent the destruction of farms, anti-open grazing laws have been made in some states where the crisis occur the most. Most of the acts criminalized and offences prohibited were gender-neutral, despite a more embracing approach on gender sensitivity in lawmaking.

This article adopts an evaluative approach to assess inclusivity and equality in the recent anti-open grazing laws in the middle belt region of Nigeria, being a region where the conflict occurs the most.

It seeks to reveal the discriminatory approach to women, in the provisions of the Anti-Open Grazing Laws (AOGL) ${ }^{10}$ in Benue State and the Open Grazing Prohibition Law $(\mathrm{OGPL})^{11}$ of Taraba State. This is important in the wake of the just suspended ${ }^{12}$ Rural Grazing Area (RUGA) policy ${ }^{13}$ of the Federal Government, which may induce citizens of some states to engage their state legislators to make laws that

Northern Nigeria' (2012) Arabian Journal of Business and Management Review (OMAN Chapter) Vol. 2, No.1, 114,

9 Abdulbarkindo Adamu and Alupsen Ben, 'Nigeria: Benue State under the shadow of "herdsmen terrorism" (2014 - 2016) (with update: 1 January - 31 August 2017)' (2017) World Watch Research, Working Paper No. 5, Abuja, Nigeria; Bukola I. Ademola-Adelehin and others, 'The Impact of Farmers Herders Conflict on Women in Adamawa, Gombe and Plateau States of Nigeria' [2018] Search for Common Ground.

10 A Law to Prohibit Open Rearing and Grazing of Livestock and Provide for the Establishment of Ranches and Livestock Administration, Regulation and Control, and for Other Matters Connected Therewith, 2017.

11 A Law to Prohibit Open Rearing and Grazing of Livestock and to provide for the Establishment of Ranches and for Other Matters Connected Thereto, 2017.

12 Emma Amaize et al, 'Why we're suspending RUGA policy implemen tation - FG' Vanguard (4 July 2019) <https://www.vanguardngr.com/2019/07/why-were-suspending-ruga-policy-implementation-fg/> accessed 12 July 2019.

13 RUGA is a proposed but now suspended policy to build legally designated communities in all states of Nigeria for the benefit of cattle herders with an initial pilot scheme for 12 states. It was conceived to create reserved communities where herders will live, grow and tend their cattle, produce milk and undertake other ancillary activities in the cattle business without having to move around in search of grazing land for their cows. Segun Ayobolu, 'Rethinking the RUGA policy', The Nations newspaper (July 6, 2019) <https://thenationonlineng.net/rethinking-the-ruga-policy/> accessed $11^{\text {th }}$ July, 2019. 
prohibit open grazing and ancillary acts that cause crisis between farmers and herders.

The article examines what gender equality and nondiscrimination under the law entails in section 2 below. This is to lay the background for discussions and analysis of the laws in order to determine whether they offer equal protection to women and men. Section 3 traces the international recognition of rape at times of conflict, first, as a reward of war and now as a weapon of war. This is to show that rape is used as a weapon in times of crisis, necessitating its prohibition. The section also discusses the lived experiences of women in the farmers-herders conflict areas, to show how rape is being used as a weapon in that region. This proves that the distinctiveness in the interactions and encounters of women are affected by gender dynamics. Section 4 deconstructs the discriminatory attitude of the laws in neglecting, ignoring and underplaying the agonizing travails and roles of women. It argues that the laws sought to promote patriarchal benefits and reinforce hegemonic male dominance. It also discusses the significant roles played by women in causing or aggravating the crisis with the recommendation to also prohibit such acts. This is because equal opportunities should come with equal responsibilities in the equality and non-discrimination discourse. Section 5 lays out recommendations on how to make the law work for women too. Section 6 is the concluding remarks.

\section{GENDER EQUALITY AND NON- DISCRIMINATION UNDER THE LAW}

The concept of gender equality is broad and can have several connotations ascribed to it. Equality here connotes equal protection under the law and nondiscrimination in fact. ${ }^{14}$ Discrimination on the basis of gender ${ }^{15}$ is prohibited under the Universal Declaration of Human Rights, ${ }^{16}$ the International

\footnotetext{
${ }^{14}$ BG Ramcharan, 'Equality and Nondiscrimination' in Stephanie Farri-or ed, Equality and Non-Discrimination under International Law, Volume II, (Taylor \& Francis Group 2017).

15 Gender and Sex are used here intermittently.

16 UDHR 1948, article 2.
} 
Covenant on Civil and Political Rights, ${ }^{17}$ the International Covenant on Economic, Social and Cultural Rights ${ }^{18}$ and the African Charter on Human and Peoples' Rights. ${ }^{19}$ Most importantly, it is prohibited under Section 42 of the 1999 Constitution of the Federal Republic of Nigeria.

The Convention on the Elimination of All Forms of Discrimination Against Women (CEDAW) expounds the legal rule on non-discrimination from a gender viewpoint. This convention moves from a gender-neutral rule which compels equal treatment of men and women, ordinarily determined by how men are treated, to one that acknowledges the fact that the distinct nature and dynamics of women require distinctive legal responses. ${ }^{20}$ This is relevant under this discourse, in highlighting that the distinct legal responses to women should be contemplated.

Article 1 of CEDAW defines discrimination against women as "any distinction, exclusion or restriction made on the basis of sex which has the effect or purpose of impairing or nullifying the recognition, enjoyment or exercise by women, irrespective of their marital status, on a basis of equality of men and women, of human rights and fundamental freedoms in the political, economic, social, cultural, civil and other field."

The underlying words here will be 'exclusion which has the effect of impairing the enjoyment by women, of human rights in the economic field'. Therefore, gender equality and non-discrimination as sought under this paper will require that the laws prohibit the illegal acts that predispose men and women to risks and harm in pursuit of their agricultural activities, which invariably drives the conflict, with an allinclusive approach. This is in order to afford protection to all, bearing in mind the gender dynamics that play out for women distinct from men.

Therefore, offering equal protection does not denote offering the same type of protection but will also require that full protection should be offered to both genders, to cover their vulnerabilities and susceptibilities presented by nature.

${ }_{17}$ ICCPR 1966, articles 2 and 26.

18 ICESCR 1966, article 2(2).

19 ACHPR 1981, articles 2 and 3 (1) and (2).

20 Rebecca Cook, 'Women's International Human Rights Law: The Way Forward' (1993) 15 Human Rights Quarterly 230, 239. 


\section{CONCEPTUALIZING AND CRIMINALIZING RAPE IN CONFLICT SITUATIONS}

Some of the main objectives of AOGL under Sections 3 (b) and $(\mathrm{f})$ are to prevent clashes between nomadic livestock herders and crop farmers and to create a conducive environment for large scale crop production, respectively.

Section 3 (d) of OGPL also aims to prevent clashes between herders and farmers while Section 3 (c) and (i) aim to prevent the destruction of farm crops and to promote and enhance productivity and high breeds of healthier livestock respectively. In order to achieve these, the law should prohibit the relevant acts that cause and aid the conflict- open grazing, ${ }^{21}$ cattle rustling, ${ }^{22}$ land grabbing, ${ }^{23}$ possession of firearms ${ }^{24}$ and rape. All these acts have been prohibited as will be seen in the next section, except rape.

This section traces the concept of rape in conflict situations to show how the international community moved from trivializing to criminalizing rape in conflict situations. It also examines the rape experiences of women in the farmersherders crisis to show that though women are affected by the prohibited acts, they are distinctively affected by rape in pursuit of their agricultural enterprises. It is hoped that the narration and accounts of the rape experiences of women, which have significantly affected their involvement in agricultural activities, will reveal how the law has not created a conducive environment for small scale crop production, let alone large scale crop production. It will also show that the

21 "Open Grazing” means the act of pasturing livestock to feed on dry grass, growing grass, shrubs, herbage, farm crops, etc, in open fields without any form of restriction. AOGL 2017, s. 2 and OGPL 2017, s. 2.

22 "Rustling" means the act of stealing or moving away farm animals with -out the consent of the owner. AOGL 2017, s. 2.

23 "Land Grabbing" means any illegal, forceful and violent takeover of traditional or State land in the urban or rural area by an individual, group or association. AOGL 2017, s. 2.

24 Section 19 (6) of AOGL, 2017 classifies the fire arms as licensed or unlicensed and bans both. 
use of rape as a weapon of warfare in these instances aggravates the crisis and undermines the objective to prevent the clashes between farmers and herders in the state.

\subsection{From a "Booty of War" to a "Weapon of War"}

Sexual violence is an aggressive and hostile act by perpetrators, used as a 'means to degrade, dominate, humiliate, terrorize and control' their victims. ${ }^{25}$ It has been argued that the causal elements in several sexually violent acts are dominance and control, not a generally perceived craving for sex. ${ }^{26}$ It is estimated that only about ten per cent of sexual violence cases are recorded. ${ }^{27}$ This means that the seriousness of the issue is more intense than the statistics portray, of the true situation of things.

Prior to the 1990s, with rare exceptions, sexual violence in conflict situations was mostly invisible. ${ }^{28}$ It moved from being invisible to being trivialized; to being deemed a private matter or rationalised as an inescapable by-product of war, a deserving reward or comfort for the fighting men. ${ }^{29}$ There was a seemingly intentional failure to prosecute sexual violence in conflict situations. It was only after rape was used as a tool of ethnic cleansing in the former Yugoslavia that the media and policy-makers began to view rape as a "weapon of war". This incidence of rape received attention, largely because it was 'a genocidal or ethnic attack than because it was an attack on women'. ${ }^{30}$

This politicization of rape and its depiction as a "weapon of war" played a part in the condemnation of sexual violence in conflict situations. ${ }^{31}$ Yet, it had a potentially degenerating aspect in implying that this use of rape was 'qualitatively

25 'Sexual violence: prevalence, dynamics and consequences' $<$ https://www.who.int/violence_injury_prevention/resources/publications/e /guidelines_chap2.pdf > 9, access. 11 July 2019.

26 Ibid.

27 <https://www.kirkensnodhjelp.no/en/about-nca/latest-news/rape-is-a weapon-of-war/> accessed 11 July 2019.

28 Rhonda Copelon, 'Gender Crimes as War Crimes: Integrating Crimes against Women into International Criminal Law' [2000] 46 McGill L.J. 217, 220.

29 Copelon, (n 28), 220.

30 Copelon, (n 28)), 223.

31 Copelon, (n 28), 223. 
different from the traditional use of women as booty'. ${ }^{32}$ Nevertheless, sexual violence during armed conflict is now recognised as a weapon of war, designed not merely to inflict bodily harm primarily on female victims, but also to frighten and humiliate them, their people and their communities. ${ }^{33}$ Articles $7(1 \mathrm{~g})^{34} ; 8(\mathrm{~b})^{35}$ and $8(\mathrm{e})^{36}$ of the 1998 Rome Statute of the International Criminal Court recognised sexual violence as crimes against humanity and war crimes respectively. This instrument will suffice to show that sexual violence during conflict has been internationally prohibited.

Rape is a form of sexual violence. Under Section 281 of the Penal Code (PC), ${ }^{37}$ rape is generally defined as a situation where a man has sexual intercourse with a woman, against her will or without her consent or with illegally or forcefully got consent. ${ }^{38}$ The trauma of rape may be worse than bodily harm for most victims. ${ }^{39}$

Rape can also be systematic, ${ }^{40}$ and strategic in its aim to disband the social structure of the attacked group. ${ }^{41}$ This paper is not oblivious of the expansion of the definition of rape under Section 1 (1) of the Violence Against Persons

32 Copelon, (n 28), 223.

33 Overseas Development Institute (ODI), 'The fallout of rape as a weapon of war' (June 2014) 1 <https://www.refworld.org/docid/53cfa34-e4.htm l> accessed 8 July 2019.

34 "For the purpose of this Statute, "crime against humanity" means any of the following acts when committed as part of a widespread or systematic attack directed against any civilian population, with knowledge of the attack ... rape, sexual slavery, enforced prostitution, forced pregnancy, enforced sterilization, or any other form of sexual violence of comparable gravity;...'

35 '(xxii) Committing rape, sexual slavery, enforced prostitution, forced pregnancy, as defined in article 7, paragraph 2 (f), enforced steriliza-tion, or any other form of sexual violence also constituting a grave bre-ach of the Geneva Conventions;...'

36 '(vi) Committing rape, sexual slavery, enforced prostitution, forced pr egnancy, as defined in article 7, paragraph 2 (f), enforced sterilization, and any other form of sexual violence also constituting a serious violation of article 3 common to the four Geneva Conventions;...'

37 The Penal Code, Cap. 89 of the Laws of Northern Nigeria,1963

38 The Penal Code, section 281 (1) and (2).

39 Bülent Diken and Carsten Bagge Laustsen, 'Becoming Abject: Rape as a Weapon of War (2005), Body Society 11 111, 113.

40 'Sexual violence as a weapon of war'< https://www.unicef.org/sowc96pk/sexviol.htm> accessed 13 July 2019.

41 Bülent Diken and Carsten Bagge Laustsen (n 39), 117. 
Prohibition Act, ${ }^{42}$ but the definition of rape under the PC will suffice for discussions here.

\subsection{The Distinct Experiences of Women in the Farmer Herders Crisis}

Wars should not be fought through the bodies of women. Yet, the experiences of women in the farmers-herders crisis in the middle belt region of Nigeria reveal otherwise. Beyond 'opportunistic rapes', a worrisome trend is the use of rape as an instrument of war in Nigeria. ${ }^{43}$ Studies and media reports recount the traumatic incidents of local women farmers and Fulani women $n o n o^{44}$ sellers, who are raped while in pursuit of their agricultural activities.

In an interview with officials of Catholic Women Association (CWO), Catholic Dioceses of Otukpo, KatsinaAla and Makurdi respectively; officials of Women wing of Methodist and Anglican Communion Church in Adoka; and the Agatu Progressive Women Union; it was revealed that several women were raped by Fulain herdsmen, while on their way to the farm in KatsinaAla, Guma, Gwer West, and Agatu Local Government Areas of Benue State..$^{45}$ Some of the victims of rape were girls under the age of 12 years. ${ }^{46}$ Some women were also forcefully taken and kept in the bush by Fulani herdsmen for several days without food while being flogged daily. ${ }^{47}$

In a study in Adamawa, Gombe and Plateau States, ${ }^{48}$ it was reported that women and girls cultivating on farms or fetching firewood from forests are allegedly targeted and

42 Violence Against Persons (Prohibition) Act, 2015.

43 Bukola I. Ademola- Adelehin and others, 'The Impact of Farmers Her ders Conflict on Women in Adamawa, Gombe and Plateau States of Nigeria' [2018] Search for Common Ground, 15.

44 Nono is the local name for traditionally fermented milk that has the consistency of yoghurt.

45 Abdulbarkindo Adamu and Alupsen Ben (n 9) 33-34.

46 Interview with Founder and Chief Executive Officer of NGO "Uma hemba" in Anune, Tarka LGA; officials of Hyarev Development association in Guma; Secretary of Nongov Progressive Union in Agasha; staff officer, Social welfare department of Ministry of Woen and Social Development, Benue State Government, Makurdi in Abdulbarkindo Adamu and Alupsen Ben (n 9).

47 Abdulbarkindo Adamu and Alupsen Ben, (n 9), 35.

48 Ademola- Adelehin and others (n 43)15. 
raped by suspected Fulani herders. ${ }^{49}$ Conversely, women and girls from the pastoral communities are allegedly targeted and raped by males suspected to be farmers while walking to sell their nono in the village markets. ${ }^{50}$

Consequently, women desert the unsafe farms and halt the sale of their processed milk, owing to fear of rape. ${ }^{51}$ This affects their productivity and threatens their sources of livelihood. The abandoned produce in the farms get spoilt and lead to huge economic loss. Trust is eroded as Fulani women are accused of spying for attackers. They are sometimes made to taste their nono to prove that it is not poisoned. ${ }^{52}$ This also affects the economic activities of the Fulani women.

The media has played a major role during periods of conflict by helping the public's understanding and perception of conflict situations. ${ }^{53} \mathrm{~A}$ media report recounted that two women were raped to death on their way to farm by Fulani youths in Plateau State. ${ }^{54}$

The Fulani in Agogo traditional area of Oyo State were accused of raping women at gunpoint in their farms, sometimes in the presence of their husbands. ${ }^{55}$

This has caused a strained relationship between the farmers and herders and identified as one of the causes of the crisis. A report by International Crisis Group notes that some of the women in Internally Displaced Persons (IDP) camps in Benue, Plateau, Adamawa, Nasarawa and Taraba states were

49 Ibid.

50 Ibid.

51 Ademola- Adelehin and others (n 43), 16-17.

52 Ibid, 17.

53 Olomojobi, Oluwafemi Temitayo, 'National Newspapers' Coverage

Of The Conflict Between Herders And Farmers In Nigeria' (2017), A

Dissertation Submitted in the Department of Mass Communication Veronica Adeleke School Of Social Sciences in Partial Fulfilment of the Requirements for the Award of the Degree of Master of Science, Babcock University, Ogun State, page v.

54 Murphy Ganagana, 'Raped to death: Two married women suffer sad fate at same spot in Plateau' Sun Newspaper (16 July 2017), <http:// sunnewsonline.com/raped-to-death-two-married-women-suffer-sadfate-at-same-spot-in-plateau/> accessed 18 July 2019.

55 Ibrahim Baidoo, 'Farmer-Herder Conflicts: A Case Study Of Fulani Herdsmen And Farmers In The Agogo Traditional Area Of The Ashanti Region' Thesis submitted to the University of Ghana, Legon in $\mathrm{Pa}$ rtial Fulfillment of the Requirement for the Award of M.A. Degree in African Studies July, 2014, 49. 
victims of rape. ${ }^{56}$ These experiences traumatize the women and trigger more crises, by leading to reprisal rapes and attacks. It has also lead to the women allegedly acting as spies and instigators. ${ }^{57}$ Since the possibility of rape increases the risk factor for women to continue to engage in their source of livelihood, and triggers more crises, it ought to and should be prohibited in clear terms.

\section{DECONSTRUCTING THE DISCRIMINATORY APPROACH OF THE LAWS ON REGULATING FHC}

Law only propagates ideologies. It doesn't generate nor discern its own logic. Therefore, in analyzing a piece of law, we must think of what informs the law, who made the law and what processes were involved in the law-making. The extent to which it positively or negatively affects individuals or groups also needs to be assessed. This section argues that the processes and letters of the laws prohibiting open grazing in Benue and Taraba States covertly promote patriarchal benefits and reinforce hegemonic male dominance while excluding women from full protection, as is discussed below.

\subsection{Engagements in the law-making process and the language of the law}

Laws are influenced by those who make them, the extent of participatory processes in the law-making and the language used in the letters of the law. The State Houses of Assembly that passed the anti-open grazing laws in both states were made up of men predominantly. For instance, there were only two women in the Benue State House of Assembly and no woman in Taraba State House of Assembly in 2017..$^{58}$ The Governors that signed the bills into laws were also men. ${ }^{59}$ The

56 'Stopping Nigeria's Spiralling Farmer-Herder Violence' (2018) Africa Report No 262, 26 July 2018, International Crisis Group, Belgium, 12.

57 Ademola- Adelehin and others (n 43), 8

58 '2017 Statistical Report on Women and Men in Nigeria, National Bu reau of Statistics', February, 2018, 78.

59 'List of State Governors' < http://www.nigeriaembassyusa.org/index.p hp?page=state-governors $>$ accessed 9 July 2019. 
implication is that the laws were created primarily by men in a male-oriented world.

This means that there was a negligible number of women voices in the House to champion the fate of women. The consequence of this is that it becomes difficult to contemplate the gender-sensitive experiences of injustice that require protection. ${ }^{60}$ Although representations can be made from women groups and not necessarily from the female legislators, a more evenly distributed number of female legislators should have increased the chances that the women distinct issues were incorporated. A more accessible public participatory public hearing which provided adequate information and sought inputs from stakeholders would have also helped. But such a participatory process was not deliberately encouraged and emphasized. For instance, in Benue State, while public hearings were simultaneously held at Otukpo, Gboko and Katsina-Ala,${ }^{61}$ there were allegations by some stakeholders that they were not invited to the public hearing and could not make their representations. ${ }^{62}$ In Taraba State, the public hearing was held in Jalingo, Wukari and Bali, but was boycotted by the Fulani herders. ${ }^{63}$ Representatives of the Ministry of Agriculture, Bureau for Local Government and Chieftaincy Affairs, the Nigerian Bar Association, NGOs and other group were present for the public hearing. The main stakeholders at the public hearing were observed to be promen groups and institutions, with no recognition of any women groups reported by the media. ${ }^{64}$ This male-dominated

${ }^{60}$ Cook, (n 20) 238.

61 'Anti-Open Grazing Law: Benue Assembly Leads Quest for Implementation' Leadership Newspaper (5 November 2017) <https://leader ship.ng/2017/11/05/anti-open-grazing-law-benue-assembly-leads quest-implementation/> accessed 6 July 2019.

62 Clement A. Oloyede, 'Nigeria: Why We Oppose Benue's Anti-Open Grazing Law - MACBAN', Daily Trust (30 January 2018) <https://allafrica.com/stories/201801310469.html> accessed 6 July 2019.

63 James Eze, 'Taraba govt agrees to review anti-open grazing law -Governors' Premium Times ( 20 February 2018) <www.premiumtimesng.com/regional/nnorth-east/259330-taraba-govt-agrees-review-an ti-open-grazing-law-governors.html> accessed 7 July 2019.

64 'Taraba lawmakers commence hearing on anti-grazing bill as herdsmen boycott session' Premium Times ( 5 July 2017) <www.premiumtimes ng.com/regional/nnorth-east/235890-taraba-lawmakers-commence-he -aring-\%E2\% 80\% 8Eanti-grazing-bill-herdsmen-boycott session.html $>$ accessed 7 July 2019. 
participatory process, without a conscious and deliberate attempt to involve women and their views will result to the outcome of that process being lopsided, with men's views and needs dominating the discourse.

Furthermore, the language of the laws on the establishment of ranches disproportionately positioned for men's significant roles in the decision making processes. For instance, the provisions of Section 6 (2) of AOGL require the approvals of the Head of the family, Kindred head, as well as the Chairman of the relevant Local Government Traditional Council. The danger is that these positions will most likely all be occupied by men, as statistics have shown. ${ }^{65}$ This disproportionately positions for men's significant roles in the decision making processes, contrary to that of women. This is amidst the existence of female-headed households, who will have to go through the male-dominated approvals and be at the mercies of the men even as landowners.

The composition of the Local Government Advisory Committee under Section 33 of AOGL and Section 10 of OGPL are also skewed to position men predominantly, with no provision for female representation.

This is because the nominated positions are traditionally occupied by men. For instance, data reveals that the local government chairmanship positions from 1999-2015 had 89 men against 5 women and 745 men against 30 women for the councillorship positions in Benue State. ${ }^{66}$ This shows that without a deliberate attempt to make positions available for women representation, such a committee may end up being made up of men exclusively. The committee is to provide full information and advice concerning the physical, economic, and other local conditions in ranches. ${ }^{67}$

\subsection{Absence of provisions on sexual and gender-based violence}

Given that the inputs of women and other stakeholders were limited during the law-making process, certain distinct gender-specific circumstances which reinforce sexual and gender-based violence against women, including rape were

\footnotetext{
${ }^{65} 2017$ Statistical Report on Women and Men in Nigeria, (n 58 ).

66 Ibid.

${ }^{67}$ AOGL, s. 32.
} 
ignored. This is notwithstanding the fact that the bodies of women and girls have been turned into battlefields as seen in the last section. The law offers protection to the lives and properties of men without adequate protection to the lives, health, and dignity of women.

One of the main objectives of the laws is to stop the crisis between farmers and herders. They also prohibit certain acts that cause and aid the crisis including open grazing ${ }^{68}$ land grabbing, ${ }^{69}$ cattle rustling, ${ }^{70}$ and possession of firearms. ${ }^{71}$ Yet, the gender-specific crimes of rape and sexual-based violence, which are significant factors in the crises that ensue were neither addressed nor the protection required for women to carry out their agricultural activities offered.

The primacy given to the provisions of the laws were directed towards protection for men within their economic pursuits and their relationship with one another. ${ }^{72}$ For instance, male beneficial offences like land grabbing, cattle rustling and carrying of arms were prohibited with up to 10 years imprisonment. ${ }^{73}$ The provision for fenced ranches ${ }^{74}$ affords a gender-neutral atmosphere for crop farmers to carry on their activities while the female crop farmers are still exposed to gender-specific risks of rape in the farms.

The argument that rape has been criminalized under the Penal Code can be countered by the argument that death resulting from certain acts, ${ }^{75}$ causing bodily harm, ${ }^{76}$ trespass, ${ }^{77}$

${ }^{68}$ AOGL 2017, s.19(1); OGPL 2017, s. 17.

${ }^{69}$ AOGL 2017, s. 19 (8).

70 AOGL 2017, s. 20 (1); OGPL 2017, s. 27.

71 AOGL 2017, s. 19 (6) and (7); OGPL 2017, s.28.

72 Rebecca Cook (n 20), 241.

73 AOGL 2017, s. 19 (8) b.

74 AOGL 2017, s. 14; OGPL, s. 7 (j).

${ }^{75}$ Penal Code s. 225, "Death resulting from the intention of causing hurt or grievous hurt...”.

76 Penal Code, s. 253 (1), "Whoever causes hurt to a person by doing an act so rashly or negligently as to endanger human life or the personal safety of others, shall be punished with imprisonment for a term which may ex-tend to one year or with fine or with both".

77 Penal Code, s. 342, "Whoever enters into or upon property in the possession of another with intent to commit an offence or to intimidate, insult or annoy a person in possession of that property, or, having law fully entered into or upon that property, unlawfully remains there with intent thereby to intimidate, insult or annoy such person or with intent to commit an offence, is said to commit criminal trespass". 
being in possession of firearms and dangerous weapons, ${ }^{78}$ maiming animals, ${ }^{79}$ stealing and theft ${ }^{80}$ are also criminalized under the Penal Code. Yet, these crimes were rightly prohibited in the anti-open grazing laws because of their distinctive roles as the proximate reasons for the conflict. For instance, cattle rustling which has been rightly prohibited under the AOGL and OGPL is prohibited and can be prosecuted under Section $330^{81}$ or Section 286 (1) of the Penal Code. ${ }^{82}$ Trespass and destruction by animals have been proscribed by the rule in Ryland v. Fletcher ${ }^{83}$ which holds the owner of any animal that causes damage liable in negligence, in nuisance, or for trespass. Nonetheless, this was rightly prohibited under Section 16 of AOGL and Section 25 (2) of OGPL, as a proximate cause of the conflict.

The proper identification of cattle rustling as a distinct crime that acts as a unique factor in the crisis is appreciated. The proper identification of land grabbing, amidst the provisions under Section 37 of the Land Use Act ${ }^{84}$ on illegal occupation of land and unlawful dispossession of one's property is also commendable. Similarly, holding the owners of cattle liable for the destructions in farms is in a bid to discourage such destructions, which is a significant trigger in the clashes. Yet, there was no proper identification and prohibition of those acts that limit women's participation in their agricultural pursuits. Women need another layer of protection from these acts before the law can be said to have offered them adequate protection, like their male counterparts. Any argument to subsume or interpret the rape offences under the provisions on injuries to the body in

${ }_{78}$ Penal Code, s. 298 (c), “... if the robbery is committed by a person armed with a dangerous or an offensive weapon or instrument, to imprisonment for life or a less term and shall also be liable to fine."

79 Penal Code, s. 330, "Whoever commits mischief by killing, poisoning, maiming or rendering useless a camel, horse, donkey, mule, bull, cow, or an ox whatever may be the value thereof shall be punished with imprisonment for a term which may extend to five years or with fine or with both.".

80 Penal Code, s. 286 (1), "Whoever, intending to take dishonestly any movable property out of the possession of a person without that person's consent, moves that property in order to take it is said to commit theft."

81 Penal Code, s. 330, see (n 79).

82 Penal Code, s. 286, see (n 80).

83 Rylands v Fletcher [1868] UKHL 1, LR 3 HL 330.

84 1978, Cap L5 LFN 2004. 
Section 19 (3) b of the AOGL does not adequately understand the degree of the effects of rape on the victims and in starting or aggravating the crisis. The traumas and psychological effects of rape have been argued to be worse than physical harm. Therefore working with the law as we have it will be positioning the law to fail to achieve some of its stated objectives.

\subsection{Non-inclusive policies for the transitional periods}

While a transitional period of six months was allowed in Benue State, ${ }^{85}$ and an indefinite time in Taraba State, ${ }^{86}$ before the enforcement of the anti-open grazing laws, no policies were put in place to cater for the already displaced women farmers who take shelter in the Internally Displaced Persons (IDP) camps. The services offered at the IDP camps are again gender-neutral, without acknowledging and making provisions for the distinct needs of women for sanitary and maternal care. Enclosed toilet and bathrooms, sanitary towels, ante-natal services and access to food are distinctive needs of women as females who go through their monthly cycles, as mothers and as caregivers.

The International Crisis Group has recorded the deplorable state of the IDP camps in Benue state. ${ }^{87}$ Most of the pregnant women and nursing mothers in the IDP camps have little or no health and sanitary facilities. The sleeping conditions further expose the women and girls to sexual harassment, assault and rape, by both outsiders and by fellow IDPs, and make them vulnerable to drastic survival mechanisms involving sexual exploitation. ${ }^{88}$

Limited provision of food puts pressure on women to engage in 'sex for food" 89 in order to feed themselves and their

85 Tahav Argezua, 'Anti-open grazing law, solution to herdsmen attacks

- Benue’ The Punch, (5 November 2017) <https://punchng.com/anti open-grazing-law-solution-to-herdsmen-attacks-benue/> accessed 9 July 2019.

86 Fikayo Olowolagba, 'Taraba suspends anti-open grazing law', Daily P -ost, (21 February 2018) <https://dailypost.ng/2018/02/21/taraba suspends-anti-open-grazing-law/> accessed 11 July, 2019. Stopping Nigeria’s Spiralling Farmer-Herder Violence (n 56) 12.

88 Ibid.

${ }^{89}$ Sex for food is a high-risk coping strategy where women engage in tran -sactional sex in exchange for money or food in order to feed their fa- 
loved ones. The government should make adequate provisions not only in preventing future crisis but also in adequately cushioning the effects of the crisis by acknowledging the distinct ways that women will suffer it, different from men.

\subsection{Acknowledging and prohibiting the role of women in the crisis}

The equality discourse promotes the allocation of equal rights, opportunities as well as responsibilities. Therefore, there is a need to identify the distinct roles that women predominately play and assign responsibilities accordingly. The stereotype that women are only victims of the crisis has been disproved with studies that show the role that women play in aggravating the crisis. There is the allegation that Fulani women act as spies for their male counterparts by gathering information from the local communities, in the guise of selling nono, for possible attacks. ${ }^{90}$ Native women have also been accused of instigating their husbands, peddling fake rumours and hate speech and sometimes chanting war songs to spur their husbands to start violence. ${ }^{91}$

They see their men as weak and brand them as 'good for nothing' who can only beat their wives and not their fellow men. ${ }^{92}$ This kind of humiliation affects the men, spites their ego and spurs them to act retaliate attacks. ${ }^{93}$

Women have also been found as accomplices in the smuggling of arms and weapons, concealed in their products for sale, used in the conflict. ${ }^{94}$

milies. Women in displacement camps in Nigeria resort to transactional sex for survival, <https://www.un.org/africarenewal/news/womendisplacement-camps-nigeria-resort-transactional-sex-survival $>$ accessed 12 November, 2019.

90 Ademola- Adelehin and others (n 43), 17.

91 Ademola- Adelehin and others (n 43), 20.

92 Ukandu Ikechukwu Maxwell and Chiaghanam Ozioma Faith, 'SocioReligious and Gender Implications of Farmer-Herder Hostilities in Contemporary Nigeria in Nwaneri Martinluther and Vande Philip eds, History and management of Farmer-herder Conflicts in Nigeria, 93 Ibid. (Veritas University Press 2019) p148.

94 Ademola- Adelehin and others (n 43), 20. 


\section{MAKING THE LAW WORK FOR WOMEN}

Having identified the ways that women have been discriminated against in section 4, this section recommends ways to make a law that seeks to prevent the destruction of crop farms and prevent clashes between nomadic livestock herders and crop farmers work for women, as it works for men.

First, the participatory process must be deliberate in including women and making their voices count. Even where there are no elected women in the legislature of the state, women should be incorporated in the whole decision making process and their opinions sought on issues as it affects them, from the very beginning of the process. The language and content of the law must also be deliberate in including women in the decision making process. For instance, for the composition of the Local Government Advisory Committee under Section 33 of AOGL and Section 10 of OGPL, there should be a deliberate inclusion of a female position to avoid an advisory committee that is made up of men only.

Secondly, the gender-specific crimes of rape and sexualbased violence, which are significant factors in the crises that ensue should be expressly prohibited so as to offer the protection required for women to carry out their agricultural activities. Without an outright ban on it, as was done for other serious offences, the law will be seen to be offering less protection to women as they cannot freely engage in their farming activities. The confidence that the law gives to men by the knowledge that land grabbing or cattle rustling has been prohibited is the kind of confidence it will give to women to know that this law will hold their perpetrators accountable.

Thirdly, the international community has advised that there should be a fairly long transitional period before the full enforcement of the ban on open grazing. ${ }^{95}$

Therefore, there should be policies put in place to cater for the distinct needs of women victims in the IDP camps, in the meantime, including secluded toilet and bathroom facilities. This will help them maintain sanitary inconveniences that come with their monthly and maternal cycles, and protect them from avoidable sexual harassment. Adequate provisions

${ }^{95}$ Stopping Nigeria's Spiralling Farmer-Herder Violence (n 56) . 
in the IDP camps will also protect women from the pressure of 'sex for food'.

Lastly, if the aims of both the AOGL and OGPL include to prevent the destruction of crop farms and prevent clashes between nomadic livestock herders and crop farmers, then ancillary actions that lead to the clashes should be adequately prohibited..$^{96}$ Thus, there is a need to prohibit such accessory offences like instigating, conspiracy and aiding in smuggling of arms and weapons.

The argument that an outright ban on open grazing will eliminate the crisis will not hold water as it has been proved that certain illegal acts asides from open grazing have in the past sparked the crisis. For instance, while the herders may conform and operate within the ranch permits, as provided under Section 5 of AOGL and Section 7 of OGPL, the herders will still live amongst the native communities and so women are still susceptible to the alleged rapes that occur in the farms which can lead to reprisal rapes. This will certainly predispose others to the ancillary acts of instigation and connivance that cause the crisis. There is, therefore, a need to inclusively prohibit such acts in order to adequately prevent clashes and promote the productivity of women crop farmers.

\section{CONCLUSION}

Women farmers in Nigeria continue to face diverse forms of assaults and attacks, including rape, women in pursuit of their agricultural endeavors. It has become an integral aspect of the farmers-herders crisis, with its attendant blame in making women not only victims of the conflict but also active actors. Yet, strangely, rape is absent as one of the acts prohibited under the anti-open grazing laws in Benue and Taraba States of the middle belt region of Nigeria, where the conflicts occur the most.

It is not obvious whether the absence of rape in the laws curtailing the farmers-herders crisis translates to laws for active encouragement, of knowing omission, of invisibilization or of toleration. ${ }^{97}$ What is certainly apparent is that they are laws of exclusion, excluding the protection that

\footnotetext{
96 The Benue law fares better in this regard, compared to the Taraba law.

97 Copelon, (n 28), 239.
} 
women should get under the laws, just like the men have their lives and properties specifically protected by the laws. While the lives and properties of women are also seemingly protected in the laws like those of the men, the existence of the distinct nature of women and the use of rape as weapons of war demand that rape is specifically prohibited and punished under the laws, notwithstanding its prohibition under the Penal Code and in the Violence Against Persons Prohibition Acts (in the states where it has been passed).

This is especially so, as the offences which were prohibited under the Anti-Open Grazing laws are also prohibited under the Penal Code, but demand prohibition in context, given the peculiar circumstances of the crisis.

The wave of RUGA is here and some more states may wish to make laws that prohibit open grazing. It is recommended that the issues raised in this paper as it affects women should be considered in any such attempts to curtail the crisis between herders and farmers. The role that women play as instigators in the conflict ought to be prohibited, in curtailing the crisis. More importantly, the risks that women distinctly suffer in the crisis ought to be contemplated and mitigated by the law. Thus sexual and gender-based violence which limits the free participation of women in their agricultural pursuits should be explicitly prohibited. Structures must also be put in place to hold authorities accountable where they fail to protect people from sexual violence, by refusing or neglecting to punish perpetrators of sexual violence, ${ }^{98}$ especially during conflict.

The law is the first step in offering protection and proscribing illegal acts so that litigants and the general public can have a tool to effectively seek justice. To avoid a covert discriminatory approach in law, the law should be made with conscious deliberations on who is making the law; what informs the making of the law; participatory processes in the law-making and a careful selection of the language and context of the law. This will help to ensure that the law works for both men and women.

98 Kristine Gronhaug, 'Rape as a weapon of war: Quite, Cheap and Scarily efficient' <https://www.nrc.no/shorthand/stories/rape-as-a-weaponof-war/index.html\#article> accessed 9 July 2019. 